\title{
NEST-AREA FIDELITY OF GREATER SAGE-GROUSE IN STRAWBERRY VALLEY, UTAH
}

\author{
Riley D. Peck ${ }^{1}$, Rick J. Baxter ${ }^{1}$, Randy T. Larsen ${ }^{2}$, and Jerran T. Flinders ${ }^{1}$
}

\begin{abstract}
Nest-area fidelity is common among many birds including those in the orders Anseriformes, Ciconiiformes, and Procellariiformes. Successful nesting attempts are often associated with a higher probability that nesting adults will return in a consecutive year. Conversely, unsuccessful birds are often less likely to show fidelity in subsequent years. Despite substantial natural history information from across the range of Greater Sage-Grouse (Centrocercus urophasianus), the prevalence of sage-grouse nest-area fidelity remains unclear. Our objectives were to (1) determine if individual female sage-grouse showed fidelity to nesting areas in subsequent years, (2) test whether successful females were more likely to demonstrate fidelity than unsuccessful females, and (3) examine the distance between nest sites and active leks in Strawberry Valley, Utah. We observed 30 radio-marked females that attempted a nest in consecutive nesting seasons between 1998 and 2010. The mean distance between initial year's nests and subsequent year's nests $(\bar{x}=$ $1459 \mathrm{~m}, \mathrm{SE}=84.9 \mathrm{~m})$ was lower $(P<0.01)$ than the mean distance from initial year's nests to random nests $(\bar{x}=13,263 \mathrm{~m}$, $\mathrm{SE}=227.5 \mathrm{~m})$ indicating that sage-grouse demonstrated nest-area fidelity. We found no support $(P>0.05)$ for the hypothesis that successful females $(n=17, \bar{x}=1355 \mathrm{~m}, \mathrm{SE}=142.6 \mathrm{~m}$ ) were more likely to nest closer to the previous nest location than unsuccessful females $(n=13, \bar{x}=1595 \mathrm{~m}, \mathrm{SE}=214.9 \mathrm{~m})$ in our study area. Mean distance from all nests $(n=181)$ to nearest active lek was $4.3 \mathrm{~km}$. We found only $57 \%$ of our nests located within the $3.2-\mathrm{km}$ distance from an active lek often used to delineate critical nesting habitat. We suggest a more conservative distance of $10 \mathrm{~km}$ for our study area and consideration of nest-area fidelity in conservation planning.
\end{abstract}

Resumen.-La fidelidad al área del nido es común entre muchas aves, incluyendo aquellas en los órdenes Anseriformes, Ciconiiformes y Procellariiformes. Los intentos exitosos de anidación están generalmente relacionados con una mayor probabilidad de que los adultos anidadores regresen en un año consecutivo. Por el contrario, las aves que fracasan tienen por lo general menos posibilidades de mostrar fidelidad en los años subsiguientes. A pesar de la información sustancial sobre su historia natural a lo largo de su rango de distribución, la prevalencia de la fidelidad al área del nido aún es poco clara en el caso del urogallo mayor (Centrocercus urophasianus). Nuestros objetivos fueron 1) determinar si el urogallo hembra muestra fidelidad a las áreas del nido en años subsiguientes, 2) examinar si las hembras exitosas tienen más posibilidades de mostrar fidelidad que las hembras que fracasan, y 3) examinar la distancia entre los sitios de anidación y los leks activos en Strawberry Valley, Utah. Observamos 30 hembras marcadas a través de radio que procuraban un nido en temporadas de anidación consecutivas entre 1998 y 2010. La distancia promedio entre los nidos del año inicial y los del año subsiguiente $(\bar{x}=1,459 \mathrm{~m} ; \mathrm{EE}=84.9 \mathrm{~m})$ fue menor $(P<0.01)$ que la distancia promedio de nidos del año inicial hacia nidos aleatorios $(\bar{x}=13,263 \mathrm{~m} ; \mathrm{EE}=227.5 \mathrm{~m})$ lo que indica que el urogallo mostró una fidelidad al área del nido. No encontramos respaldo $(P>0.05)$ para la hipótesis que indicaba que las hembras exitosas $(n=$ $17 ; \bar{x}=1,355 \mathrm{~m} ; \mathrm{EE}=142.6 \mathrm{~m}$ ) tienen más posibilidades de anidar más cerca de la ubicación previa del nido que las hembras que fracasan $(n=13 ; \bar{x}=1,595 \mathrm{~m} ; \mathrm{EE}=214.9 \mathrm{~m})$ en nuestra área de estudio. La distancia promedio desde todos los nidos $(n=181)$ hasta el lek activo más cercano fue de $4.3 \mathrm{~km}$. Encontramos sólo $57 \%$ de nuestros nidos ubicados a una distancia de $3.2 \mathrm{~km}$ desde un lek activo que generalmente se usa para delimitar el hábitat de anidación crítico. Sugerimos una distancia más conservadora de $10 \mathrm{~km}$ para nuestra área de estudio y la consideración de la fidelidad al área del nido para planificar la conservación.

Nest-area fidelity is common among many birds including those in the orders Anseriformes, Ciconiiformes, and Procellariiformes (Cezilly et al. 2000, Blums et al. 2002, Bried et al. 2003). Fidelity to nesting areas may increase fitness and reduce risks associated with nesting in new habitat (Bergerud and Gratson 1988). Increased fitness can result from reduced rates of nest predation, higher fledging rates, and increased survival of nesting adults in familiar, quality nesting habitat (Greenwood and Harvey 1982). Successful nesting attempts (defined as hatching one or more chicks) are often associated with a higher probability that the nesting adult returns in a subsequent year. Conversely, unsuccessful birds are often less likely to show

\footnotetext{
${ }^{1}$ Department of Plant and Wildlife Sciences, Brigham Young University, 275 WIDB, Provo, UT 84602

${ }^{2}$ Corresponding author. Department of Plant and Wildlife Sciences and Monte L. Bean Life Science Museum, Brigham Young University, 407 WIDB, Provo, UT 84602. E-mail: randy_larsen@byu.edu
} 
fidelity in subsequent years. This general relationship has been demonstrated in a variety of birds (Greenwood and Harvey 1982).

Despite substantial natural history information for Greater Sage-Grouse (Centrocercus urophasianus-hereafter referred to as sagegrouse), the prevalence of nest-area fidelity and factors associated with this behavior remain unclear. Several studies suggest sage-grouse demonstrate fidelity to nesting areas (Fischer et al. 1993, Schroeder and Robb 2003, Holloran and Anderson 2005, Moynahan et al. 2007, Connelly et al. 2011), but the relationship between nest success and nest-area fidelity, in particular, is ambiguous (Connelly et al. 2011). Some research, for example, shows significantly greater nest-area fidelity between years for successful females compared to unsuccessful females (Schroeder and Robb 2003, Holloran and Anderson 2005), whereas in other populations, this relationship was not evident (e.g., Herman-Brunson 2007, Kaczor et al. 2011).

Furthermore, the relationship between nests and leks (communal breeding grounds where sage-grouse congregate each spring) also varies across populations (Connelly et al. 2011). Despite this variation, however, managers often consider the area within $3.2 \mathrm{~km}$ of active leks to be critical nesting habitat. This guideline was based on earlier research suggesting the majority $(59 \%-87 \%)$ of sage-grouse nested within this distance of an active lek (Braun et al. 1977). This idea was challenged, however, by Wakkinen et al. (1992), who reported that nests were distributed randomly with respect to leks and that grouse did not select habitats around leks for nesting. More recently, Holloran and Anderson (2005) demonstrated a scaled relationship across distances for leks and nests in contiguous habitat. Disturbance and habitat fragmentation, however, may alter this relationship and influence placement of nests, with sage-grouse in disturbed or fragmented areas often traveling farther from leks to nest than those in undisturbed and contiguous habitats (Schroeder et al. 1999, Lyon and Anderson 2003, Connelly et al. 2011).

Given the conservation challenges associated with sage-grouse, it is important that we understand more about nesting ecology and nest-area fidelity. Strong site fidelity may become increasingly important for small populations in places where prime sage-grouse habitat is fragmented. While range-wide management is ideal, focus on high-use areas allows for identification of smaller-scale problems that are more easily managed. Twelve years of telemetry-based research in Strawberry Valley, Utah, provided an opportunity to examine nesting ecology of sage-grouse in a fragmented landscape in greater detail. Our specific objectives were to (1) determine if individual sage-grouse showed nest-area fidelity in subsequent years, (2) test whether successful females were more likely to demonstrate fidelity than unsuccessful females, and (3) examine the spatial relationship between nests and locations of active leks. We predicted that successful females would be more likely to show nest-area fidelity than unsuccessful females.

\section{STUdy AreA}

We investigated nesting ecology and nestarea fidelity of sage-grouse in Strawberry Valley, Utah (Fig. 1), located in the north central part of the state (coordinates near center of valley: NAD 83, Zone 12T, UTM $0492078 \mathrm{~N}$, 4445216 E). Strawberry Valley is approximately $24 \mathrm{~km}$ long and $9 \mathrm{~km}$ wide. It is characterized by mountain ridges and high mountain meadows, with elevations ranging from 2250 to $2600 \mathrm{~m}$. The valley experiences cool, dry summers and cold, wet winters. Average annual precipitation was $79 \mathrm{~cm}$ (http://nrcs.usda gov). Strawberry Reservoir is the most dominant feature of the valley, covering 6950 ha of historically occupied riparian and sagebrush steppe habitat. Over 9000 ha of sagebrush habitat existed within Strawberry Valley during our study years, but this acreage was fragmented by the reservoir, recreational homes, highways, and natural vegetation changes. The existing sage-grouse habitat in Strawberry Valley was characterized as montane sagebrush steppe, with mountain big sagebrush (Artemisia tridentata ssp. vaseyana) and silver sagebrush (Artemisia cana) as predominant shrubs. A more detailed description of our study area is available in Baxter et al. (2008) and Bunnell et al. (2004).

\section{Methods}

We captured grouse during spring (late March-April) and fall (September-November) of 1998-2010 by netting them from pickup trucks and all-terrain vehicles. We began $2 \mathrm{~h}$ after sunset, implementing a modified spotlight 


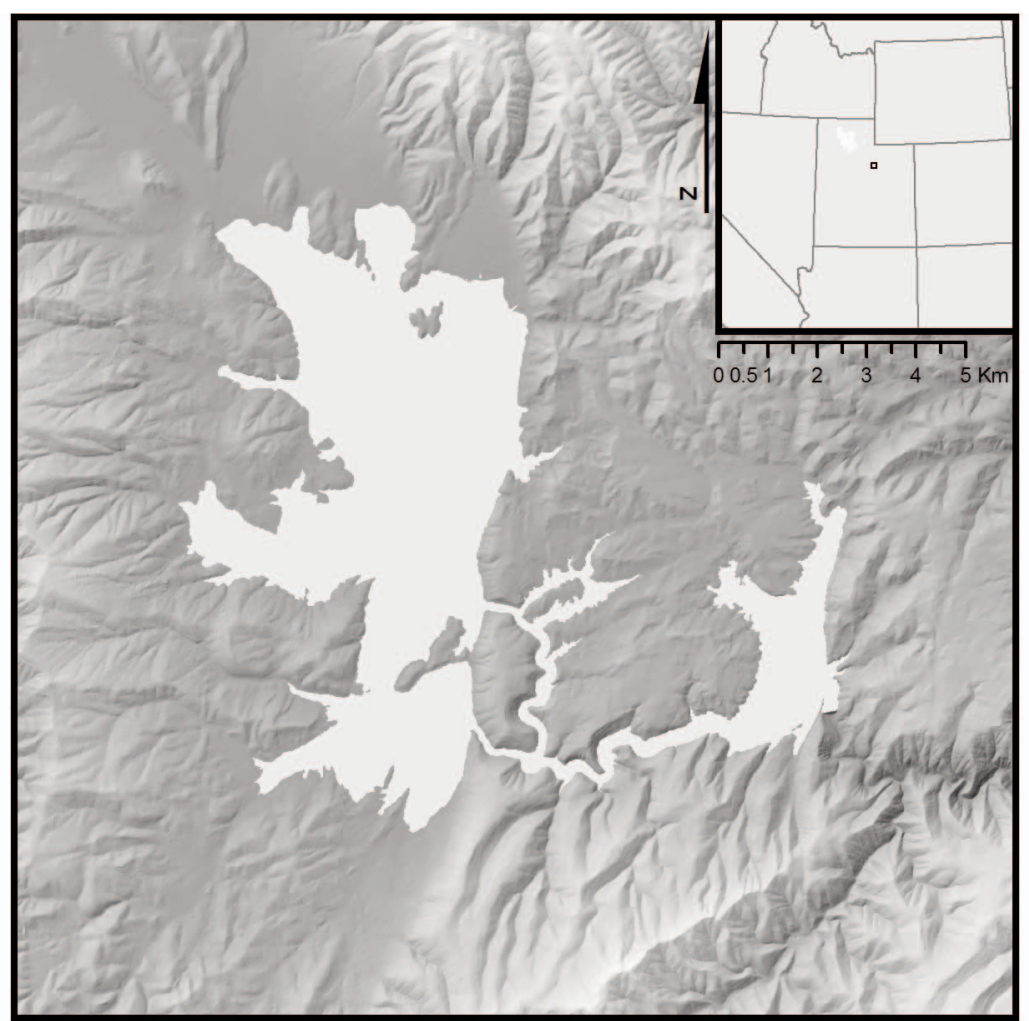

Fig. 1. Strawberry Valley study area in north central Utah where we identified Greater Sage-Grouse nests, 1998-2010.

method (Wakkinen et al. 1992). We fitted each captured female with a 22-g necklace-style radio-transmitter (Advanced Telemetry Systems, Inc., Isanti, MN; 19-h duty cycle, 45 pulses $\cdot \min ^{-1}$ with mortality signal indication after $8 \mathrm{~h}$, and maximum battery life of 30 months) prior to release at the capture location. We tracked radio-marked sage-grouse weekly from the ground with a 4-element Yagi antenna and either a TR2 (Telonics Inc., Mesa, AZ) or R-1000 radio receiver (Communication Specialists Inc., Orange, CA). In addition to monitoring from the ground, we periodically used a fixed-wing aircraft to locate radiomarked birds ( $\bar{x}=6$ flights per year).

We identified nest locations by homing radiomarked birds until we made visual confirmation of nesting females. We recorded all coordinate locations in UTM NAD 83 using a Garmin global positioning system (GPS). We then determined nest fate after a female completed her nesting attempt by examining egg membrane condition and/or by visual documentation of a female with brood. We assumed that if an egg membrane separated from the shell, a chick had hatched successfully (Klebenow 1969). We considered a nesting attempt successful when $\geq 1$ of the eggs hatched. Throughout this process, we made every attempt to minimize observerinduced abandonment of nests by sage-grouse, although a limited number $(n=14 ; \bar{x}=1.2$ per year) occurred over 12 years. When abandonment associated with observers occurred or nest loss from other sources occurred, we excluded any re-nests within the same year from our analysis.

To evaluate the spatial relationship between nests and active leks, we measured the distance between each nest and the closest active lek with ArcGIS (version 9.3; ESRI, Redlands, CA). We identified active leks using historical information coupled with both ground and helicopter surveys, and we were confident all active leks were located, given the search effort expended each spring and the large number of sage-grouse $(>500)$ radio-marked throughout 


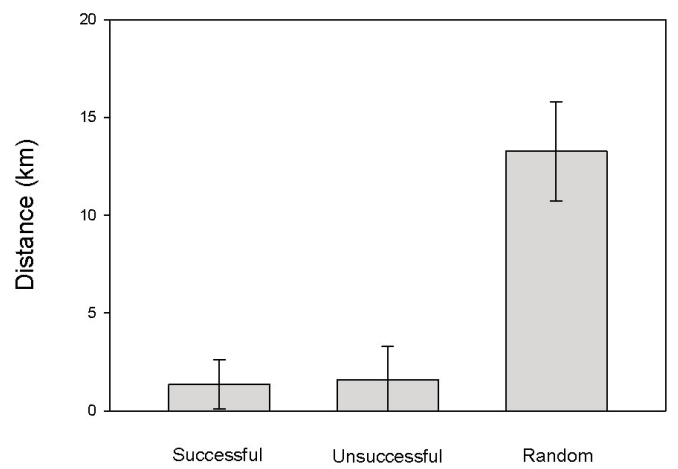

Fig. 2. Mean distance (95\% CIs) between initial-year nests and subsequent-year nests for successful and unsuccessful female Greater Sage-Grouse in Strawberry Valley, Utah (1998-2010), along with mean distance from these nests to random nest sites.

the study period. To avoid problems with pseudoreplication, we only used distances between the first nest and the nearest active lek from the birds for which we had subsequentyear nesting data (Magaña et al. 2011). To test the hypothesis that successful females would demonstrate greater nest-area fidelity than unsuccessful females, we calculated the distance between an initial nesting attempt in one year and the subsequent nesting attempt in the following year for all grouse that nested in sequential years. We then created random nests by first defining an area, using a $95 \%$ kernel density estimate around all known nests. Once this polygon was created, we created an equal number of random points within it to serve as random nesting locations. Finally, we measured the distance between initial-year and subsequent-year nests for sage-grouse, as well as the distances between initial-year nests and random locations for comparison. We considered the data too sparse to evaluate the influence of age on nest-area fidelity.

We calculated distances for the following 3 groups: successful first-year nests to secondyear nests, unsuccessful first-year nests to second-year nests, and initial-year nests (successful or unsuccessful) to the nearest random point. Initial evaluation suggested that distances were not normally distributed and that variance was not equal between groups. Consequently, we used a Kruskal-Wallis nonparametric test to determine if differences existed between groups (Whitlock and Schluter 2009). Following a significant result with this analysis, we used the nonparameteric rank-sum test (Whitlock and Schluter 2009) for pairwise comparisons (successful initial-year's nest to subsequent-year's nest, unsuccessful initial-year's nest to subsequent-year's nest, and initial-year's nest to random nest). We used the Bonferroni correction to adjust $P$ values for these multiple tests (Dunn 1961). We used version 2.7 of program $\mathrm{R}$ to conduct all statistical analyses (R Development Core Team 2009).

\section{RESUlts}

We documented 181 nests (resident hen nests $=89$; translocated hen nests $=92$ ) over the 12-year study period (1998-2010). Of these, 30 constituted a subsequent-year's nesting attempt. Mean distance between all initial-year nests and subsequent-year nests was $1459 \mathrm{~m}$ (range 57-9560 m). After removing 3 outliers that exerted a disproportionately large influence on the mean (distance $>5000 \mathrm{~m}$ ), average distance between first and subsequent-year nests dropped to $882 \mathrm{~m}$ (range 57-1916 m). Mean distance from initial-year's nest to closest random nest was 13,263 m (range 614-26,047 m). Mean distance between initial-year's nests and subsequent-year's nests was lower $(P<0.01)$ than mean distance from initial-year's nests to random nests (Fig. 2) indicating nest-area fidelity. We found no support, however, for the hypothesis that successful females would demonstrate greater nest-area fidelity than unsuccessful females, as mean distances between initial- and subsequent-year's nests were not different $(P>0.9)$. Successful females $(n=17)$ had a mean distance of $1355 \mathrm{~m}$, with a median of $367 \mathrm{~m}$ (range 57-5066 m), compared to unsuccessful females $(n=13)$ with a mean distance of $1595 \mathrm{~m}$ and a median of $345 \mathrm{~m}$ (range 78-9560 m). Mean distance between all nests $(n=181)$ and nearest active lek was $4.3 \mathrm{~km}$, with a median of $2.6 \mathrm{~km}$ (range $0.11-14 \mathrm{~km}$ ). We found only $57 \%$ of our nests located within $3.2 \mathrm{~km}$ of the nearest active lek. A plot of each nest's distance to the nearest active lek showed 2 distinct break points, as $64 \%$ of nests occurred within $4 \mathrm{~km}$ and $95 \%$ within $10 \mathrm{~km}$ (Fig. 3).

\section{Discussion}

Sage-grouse in Strawberry Valley demonstrated fidelity to nesting areas in subsequent years. Mean distance between the initial-year's nest and subsequent-year's nest was $882 \mathrm{~m}$ 


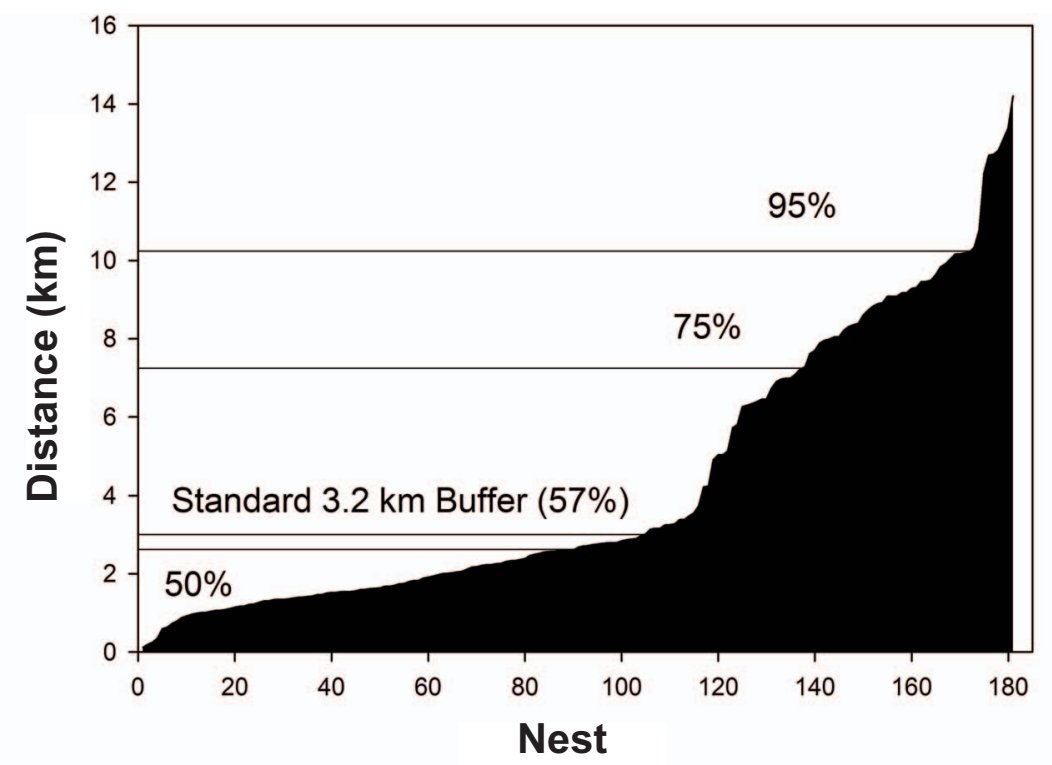

Fig. 3. Histogram showing distances from Greater Sage-Grouse nests in Strawberry Valley, Utah, to nearest active lek, $1998-2010$

(after removal of 3 outliers) compared to both seasonal and annual space-use patterns of this species, which can be as large as $31 \mathrm{~km}^{2}$ (Wallestad 1975, Connelly and Markham 1983, Gates 1983, Robertson 1991, Leonard et al. 2000). Our observed mean and median distances between consecutive nests were similar to others reported in the literature that ranged between $0.7 \mathrm{~km}$ and $3.0 \mathrm{~km}$ (Connelly et al. 2011).

We found no support for the hypothesis that successful females would be more likely to return to the same nesting area than unsuccessful females in our area. This result was similar to existing information from some populations (Fischer et al. 1993, Herman-Brunson 2007, Kaczor et al. 2011) but not others (Schroeder and Robb 2003, Holloran and Anderson 2005). Although successful hens did have a smaller mean distance between consecutive nests (successful females $=1355 \mathrm{~m}$, unsuccessful females $=1595 \mathrm{~m}$ ), confidence intervals showed large overlap, and formal tests for a difference were not significant. Fischer et al. (1993) suggested that nest selection reflected a strategy to avoid previous nests, regardless of their fate, and to avoid areas that predators may be more likely to search. By moving subsequentyear nests $500-1000 \mathrm{~m}$ sage-grouse may balance risk from predators, focusing on immediate areas around previous nests and benefits of nesting in quality habitat. Predators of willow ptarmigan (Lagopus lagopus) nests, for example, concentrated searches in areas where they had previously located nests (O'Reilly and Hannon 1989). While fidelity was evident, something other than nest success appears to have influenced sage-grouse nest-area fidelity in Strawberry Valley.

Another hypothesis for selection of nesting areas in successive years suggests that both habitat type and habitat disturbance influence choice. Storaas and Wegge's (1987) study on nesting Capercaillie (Tetrao urogallus) found that 4 out of 5 successful females, and 8 out of 14 unsuccessful birds changed habitat types in consecutive years. Similarly, Connelly et al. (1991) argued that sage-grouse may minimize risks of nesting in unsuitable areas by showing some flexibility for selection of nesting habitat. Fidelity to an area with quality nesting habitat without returning to the exact nesting location may be a demonstration of limited flexibility. Nonetheless, continued research will be required in order to more fully understand the mechanisms behind nest-area fidelity observed in sage-grouse.

For managers, knowledge of nest-area fidelity may be beneficial in identification and conservation of critical nesting areas. This information could allow managers to fine-tune 
management actions and recommendations. We recognize that this information requires multiple years of reliable telemetry data and that such information may not always be available. Where detailed telemetry information is not available, it may benefit sage-grouse to increase the commonly used $3.2-\mathrm{km}$ buffer around leks to protect nesting habitat. In our study, only $57 \%$ of all nests were located within this buffer. These results are similar to Wakkinen et al. (1992), who reported only 55\% of nests within $3.2 \mathrm{~km}$ of active leks. Other recent literature from several populations throughout the range of sage-grouse further supports increased distances from leks-particularly for disturbed or fragmented habitats (see Connelly et al. 2011 for discussion). For our study area, a distance of $4 \mathrm{~km}$ encompassed $64 \%$ of nests, whereas a distance of 10 $\mathrm{km}$ covered $95 \%$. While a $3.2-\mathrm{km}$ buffer around leks would have encompassed more than half of our nests, given the current status of sagegrouse, we suggest a conservative approach with larger buffers around active leks in order to help conserve sage-grouse populations.

Our lek-to-nest distance data challenged the commonly accepted practice of designating the area within $3.2 \mathrm{~km}$ of an active lek as critical nesting habitat (Braun et al. 1977). Where appropriate data are available, we suggest that nest-area fidelity be used to define which areas should be conserved. Identification of these areas may help limit unnecessary disturbances during critical nesting periods and ensure that proper nesting habitat guidelines are met. In areas where fidelity data are not available, an increased buffer size (up to $10 \mathrm{~km}$ ) should be considered, because increasing the buffer size around active leks will ensure protection of a higher percentage of sage-grouse nests.

\section{ACKNOWLEDGMENTS}

We thank Dr. John Rice and the Utah Reclamation Mitigation and Conservation Commission along with the Utah Division of Wildlife Resources and USDA Forest Service for logistical and financial support. In addition, Brigham Young University and Sportsmen for Fish and Wildlife (SFW) provided resources helpful to this work. We thank Jared Baxter, Josh Kaze, Jared Oyster, and Cooper MacCourtney, along with other technicians who worked on this project over the years. Drs. Frank Howe and Steve Petersen provided a helpful review of an earlier draft of this manuscript.

\section{Literature Cited}

Baxter, R.J., J.T. Flinders, and D.L. Mitchell. 2008. Survival, movements, and reproduction of translocated Greater Sage-Grouse in Strawberry Valley, Utah. Journal of Wildlife Management 72:179-186.

Bergerud, A.T., and M.W. Gratson. 1988. Adaptive strategies and population ecology of northern grouse. University of Minnesota Press, Minneapolis, MN.

Blums, P., J.D. Nichols, AND J.E. Hines. 2002. Sources of variation in survival and breeding site fidelity in three species of European ducks. Journal of Animal Ecology 71:438-450.

Braun, C.E., T. Britt, and R.O. Wallstead. 1977. Guidelines for maintenance of sage-grouse habitats. Wildlife Society Bulletin 5:99-106.

Bried, J., D. Pontier, and P. Jouventin. 2003. Mate fidelity in monogamous birds: a re-examination of the Procellariiformes. Animal Behavior 65:235-246.

Bunnell, K.D., J.T. Flinders, D.L. Mitchell, and J.H. WARDER. 2004. Occupied and unoccupied sagegrouse habitat in Strawberry Valley, Utah. Journal of Range Management 57:524-531.

Cezilly, F., F. Dubois, and M. Pagel. 2000. Is mate fidelity related to site fidelity? A comparative analysis in Ciconiiforms. Animal Behavior 59:1143-1152.

Connelly, J.W., C.A. Hagen, And M.A. Schroeder. 2011. Characteristics and dynamics of Greater Sage-Grouse populations. Studies in Avian Biology 38:53-67.

Connelly, J.W., and O.D. MarkhaM. 1983. Movements and radionuclide concentrations of sage-grouse in southeastern Idaho. Journal of Wildlife Management 47:169-177.

Connelly, J.W., W.L WaKkinen, A.D. APA, AND K.P. REESE. 1991. Sage-grouse use of nest sites in southeastern Idaho. Journal of Wildlife Management 55: 521-524.

Dunn, O.J. 1961. Multiple comparisons among means. Journal of the American Statistical Association 56: 52-64.

Fischer, R.A., A.D. APA, W.L. WAKkinen, K.P. REese, AND J.W. Connelly. 1993. Nesting-area fidelity of sagegrouse in southeastern Idaho. Condor 95:1038-1041.

GATES, R.J. 1983. Sage-grouse, lagomorph, and pronghorn use of a sagebrush grassland burn site on the Idaho National Engineering Laboratory. Master's thesis, Montana State University, Bozeman, MT.

GreenwoOd, P.J., And P.H. Harvey. 1982. The natal and breeding dispersal of birds. Annual Review of Ecology, Evolution, and Systematics 13:1-21.

Herman-Brunson, K.M. 2007. Nesting and brood-rearing success and habitat selection of Greater SageGrouse and associated survival of hens and broods at the edge of their historic distribution. Master's thesis, South Dakota State University, Brookings, SD.

Holloran, M.J., AND S.H. Anderson. 2005. Spatial distribution of Greater Sage-Grouse nests in relatively contiguous sagebrush habitats. Condor 107:742-752.

Kaczor, N.W., K.C. Jensen, R.W. Klaver, M.A. Rumble, K.M. Herman-Brunson, and C.C. Swanson. 2011. 
Nesting success and resource selection of Greater Sage-Grouse. Studies in Avian Biology 39:103-117.

Klebenow, D.A. 1969. Sage-grouse nesting and brood habitat in Idaho. Journal of Wildlife Management 33:649-661.

Leonard, K.M., K.P. Reese, and J.W. Connelly. 2000. Distribution, movements, and habitats of sage-grouse Centrocercus urophasianus on the Upper Snake River Plain of Idaho: changes from the 1950's to the 1990's. Wildlife Biology 6:265-270.

Lyon, A.G., And S.H. Anderson. 2003. Potential gas development impacts on sage-grouse nest initiation and movement. Wildlife Society Bulletin 31:486-491.

Magaña, M., J.C. Alonso, J.A. Alonso, C.A. Martín, B. Martín, and P. Palacín. 2011. Great Bustard (Otis tarda) nest locations in relation to leks. Journal of Ornithology 152:541-548.

Moynahan, B.J., M.S. LindberG, J.J. Rotella, and J.W. Thomas. 2007. Factors affecting nest survival of Greater Sage-Grouse in northcentral Montana. Journal of Wildlife Management 71:1773-1783.

O’Reilly, P., and S.J. Hannon. 1989. Predation of simulated Willow Ptarmigan nests: the influence of density and cover on spatial and temporal patterns of predation. Canadian Journal of Zoology 67:1263-1267.

R Development Core Team. 2009. R: a language and environment for statistical computing. R Foundation for Statistical Computing, Vienna, Austria. ISBN 3 900051-07-0. Available from: http://www.R-project.org
Robertson, M.D. 1991. Winter ecology of migratory sagegrouse and associated effects of prescribed fire in southeastern Idaho. Master's thesis, University of Idaho, Moscow, ID.

Schroeder, M.A., AND L.A. RobB. 2003. Fidelity of Greater Sage-Grouse Centrocercus urophasianus to breeding areas in a fragmented landscape. Wildlife Biology 9:291-299.

Schroeder, M.A., J.R. Young, and C.E. Braun. 1999. Sage grouse (Centrocercus urophasianus). In: A. Poole and F. Gill, editors, The birds of North America, No. 425. Academy of Natural Sciences, Philadelphia, PA, and American Ornithologists' Union, Washington, DC.

StoraAs, T. AND P WEGGE. 1987. Nesting habitats and nest predation in sympatric populations of capercaillie and Black Grouse. Journal Wildlife Management 51:167-172.

Wakkinen, W.L., K.P. Reese, and J.W. Connelly. 1992. Sage-grouse nest locations in relation to leks. Journal of Wildlife Management 56:379-381.

WallestaD, R.O. 1975. Male sage-grouse responses to sagebrush treatment. Journal of Wildlife Management 39:482-484.

Whitlock, M.C., AND D. SCHLuter. 2009. The analysis of biological data. Roberts and Company, Greenwood Village, CO.

Received 9 December 2011 Accepted 12 July 2012 